\title{
JNPH
}

Volume 7 No. 2 (Oktober 2019)

(C) The Author(s) 2019

\section{HUBUNGAN KADAR ASAM URAT DENGAN TEKANAN DARAH PADA LANJUT USIA (LANSIA) DI BALAI PELAYANAN DAN PENYANTUNAN LANJUT USIA (BPPLU) PAGARDEWA KOTA BENGKULU}

\author{
THE RELATIONSHIP OF URATIC ACID LEVELS WITH BLOOD PRESSURE ON \\ THE AGE OF THE AGE (ELDERLY) IN THE AGENCY OF THE AGE OF SERVICES \\ AND ADMINISTRATION (BPPLU) PAGAR DEWA KOTA BENGKULU
}

\author{
JON FARIZAL, PUTRI WIDELIA WELKRIANA, RINI PATRONI \\ POLTEKKES KEMENKES BENGKULU \\ JALAN INDRAGIRI NOMOR 03 PADANG HARAPAN KOTA BENGKULU 38225 \\ Email: jonfarizal77@gmail.com
}

\begin{abstract}
ABSTRAK
Latar Belakang: Hipertensi merupakan salah satu penyebab utama kematian di dunia. Faktor resiko terjadinya tekanan darah tinggi (hipertensi) salah satunya yaitu asam urat. Salah satu faktor resiko peningkatan kadar asam urat yang tidak bisa diubah adalah usia. Semakin bertambahnya usia, fungsi tubuh juga mengalami kemunduran. Lebih dari 50\% dari jumlah lansia yang berada di Balai Pelayanan dan Penyantunan Lanjut Usia (BPPLU) Pagar Dewa Kota Bengkulu menderita hipertensi. Tujuan: Untuk mengetahui hubungan kadar asam urat dengan tekanan darah pada lanjut usia (lansia) di Balai Pelayanan dan Penyantunan Lanjut Usia (BPPLU) Pagar Dewa Kota Bengkulu. Metode: Menggunakan desain cross sectional dengan sampel 34 responden. Data diperoleh melalui pemeriksaan tekanan darah dan kadar asam urat. Data dianalisis dengan menggunakan Statistical Product and Service Solution (SPSS) dan uji Chi Square. Hasil: Hasil analisis univariat didapatkan sebagian besar responden yang memiliki tekanan darah tinggi (52,9\%), sedangkan hampir sebagian responden yang memiliki tekanan darah normal $(47,1 \%)$, sebagian besar responden yang memiliki kadar asam urat tinggi $(61,8 \%)$, sedangkan hampir sebagian responden yang memiliki kadar asam urat normal (38,2\%). Hasil analisis uji Chi Square menunjukkan secara statistik ada hubungan yang bermakna antara kadar asam urat dengan tekanan darah pada lansia $\mathrm{P}=0,0001(\mathrm{P}<0,05)$. Kesimpulan: Ada hubungan yang bermakna antara asam urat dengan tekanan darah pada lansia.
\end{abstract}

\section{Kata Kunci: Kadar Asam Urat, Tekanan Darah, Lansia}

\begin{abstract}
Background: Hypertension is one of the leading causes of death in the world. One of the risk factors for high blood pressure (hypertension) is gout. One risk factor for elevated uric acid levels that cannot be changed is age. As we get older, bodily functions also decline. More than $50 \%$ of the number of elderly people who are in the Service Center and Elderly Support (BPPLU) Bengkulu City Fence suffer from hypertension. Objective: To determine the relationship of uric acid levels with blood pressure in the elderly (elderly) in the Service Center and Elderly Assistance (BPPLU) Bengkulu City Fence. Method: Using a cross sectional design
\end{abstract}


with a sample of 34 respondents. Data obtained through examination of blood pressure and uric acid levels. Data were analyzed using Statistical Product and Service Solution (SPSS) and Chi Square test. Results: The results of univariate analysis showed that most respondents had high blood pressure $(52.9 \%)$, while almost all respondents had normal blood pressure $(47.1 \%)$, the majority of respondents who had high uric acid levels $(61.8 \%) \%$ ), while almost the majority of respondents had normal uric acid levels $(38.2 \%)$. Chi Square test analysis results showed a statistically significant relationship between uric acid levels with blood pressure in the elderly $\mathrm{P}$ $=0.0001(\mathrm{P}<0.05)$. Conclusion: There is a significant relationship between gout and blood pressure in the elderly.

\section{Keywords: Uric Acid Levels, Blood Pressure, Elderly}

\section{PENDAHULUAN}

Tekanan darah tinggi atau hipertensi merupakan masalah kesehatan yang cukup dominan baik di negara maju maupun negara berkembang (Novitasari dan Tatius, 2014). Berdasarkan Riset Kesehatan Dasar (Riskesdas) 2013, prevalensi hipertensi di Indonesia sebesar 26,5\% (Badan Penelitian dan Pengembangan Kesehatan, 2013). Selain prevalensi yang tinggi, hipertensi juga dapat menimbulkan banyak komplikasi dalam perjalanan penyakitnya. Hipertensi merupakan salah satu kontributor beban penyakit global yang utama sebagai faktor resiko, penyebab morbiditas dan mortalitas dari penyakit kardiovaskular serta ginjal. Berbagai studi telah dilakukan untuk mengetahui berbagai faktor resiko dan interaksinya terhadap timbulnya komplikasi pada individu penderita hipertensi. Beberapa faktor resiko tersebut antara lain obesitas, usia, diabetes melitus dan kadar asam urat (Clement. dkk. 2014).

Faktor resiko peningkatan kadar asam urat yang tidak bisa dikendalikan (non modifiable) adalah usia dan jenis kelamin (Qiu. dkk. 2013). Pada laki-laki kadar asam urat akan terus bertambah dan meningkat seiring dengan bertambahnya usia (Sofia dan Gusti, 2017). Sedangkan pada wanita mengalami peningkatan kadar asam urat setelah masa menopause (Savitri, 2017).

Proses pembentukan asam urat akan menghasilkan produk sampingan berupa $\mathrm{XDH}$ (Xanthine dehydrogenase) dan XO (Xanthine oxidase) yang memiliki kemampuan memproduksi superoksida yang paling sering berkontribusi pada disfungsi endotel jantung. Superoksida akan mengganggu fungsi dari NO (Nitrit oksida) dan menyebabkan disfungsi endotel serta stress oksidatif. Disfungsi endotel yang terjadi dipercaya berperan penting dalam pembentukan aterosklerosis dan menjadi faktor resiko berbagai penyakit kardiovaskuler (Syahfitri dan Joseph, 2016). Peningkatan kadar asam urat dalam darah memiliki efek pada ginjal dan pembuluh darah, sehingga dapat menyebabkan penurunan NO dan peningkatan ROS, inflamasi vaskuler dan proliferasi otot polos, peningkatan produksi renin dan lesi vaskuler pada ginjal (Pualillin. dkk. 2015).

Hubungan antara kadar asam urat tinggi (hiperurisemia) dengan tekanan darah (hipertensi) semakin diperkuat oleh studi eksperimental dengan hewan coba tikus yang dilakukan oleh Youssef pada tahun 2013. Pada studi tersebut, tikus diberi penghambat uricase, yaitu oxonic acid, kemudian diberi preparat asam urat. Ketika uricase dihambat, asam urat tidak dapat diubah menjadi allantoin yang bersifat lebih larut dan dapat diekskresi melalui urin. Setelah 1-4 minggu terjadi peningkatan tekanan pada darah tikus (Youssef, 2013).

Berdasarkan uraian di atas kita ketahui bahwa peran asam urat sebagai faktor resiko tekanan darah tinggi (hipertensi) masih merupakan kontroversi. Maka, saya sebagai peneliti tertarik untuk mengetahui apakah ada hubungan kadar asam urat dengan tekanan darah pada lanjut usia (Lansia). 


\section{METODE PENELITIAN}

Jenis penelitian yang dilakukan bersifat analitik dengan pendekatan cross sectional. Penelitian ini dilakukan di Balai Pelayanan Dan Penyantunan Lanjut Usia (BPPLU) Pagar Dewa Kota Bengkulu dan di Laboratorium Terpadu Poltekkes Kemenkes Bengkulu pada bulan April-Mei 2018. Sampel penelitian ini diambil dengan metode Total Sampling yang terdiri dari 34 orang responden yang dipilih sesuai dengan kriteria inklusi sampel.

\section{HASIL}

Hasil analisis univariat dan analisis bivariat dari kadar asam urat dan tekanan darah pada lanjut usia (lansia) disajikan pada tabel 4.1 dan tabel 4.2.

Tabel 1 Distribusi frekuensi tekanan darah dan kadar asam urat pada lansia

\begin{tabular}{cccccc}
\hline $\begin{array}{c}\text { Tekanan } \\
\text { Darah }\end{array}$ & Frekuensi & $\begin{array}{c}\text { (\%) } \\
\text { Normal }\end{array}$ & $\begin{array}{c}\text { Kadar } \\
\text { Urat }\end{array}$ & $\begin{array}{c}\text { Frekue } \\
\text { nsi }\end{array}$ & $(\%)$ \\
\hline Normal & 16 & $\begin{array}{c}47, \\
1 \%\end{array}$ & Normal & 13 & $38,2 \%$ \\
\hline Tinggi & 18 & $\begin{array}{c}52, \\
9 \%\end{array}$ & Tinggi & 21 & $61,8 \%$ \\
\hline Total & 34 & $\begin{array}{c}100 \\
\%\end{array}$ & Total & 34 & $100 \%$ \\
\hline
\end{tabular}

Tabel 1 diketahui sebagian besar responden yang memiliki tekanan darah tinggi $(52,9 \%)$. Diketahui sebagian besar responden yang memiliki kadar asam urat tinggi $(61,8 \%)$.

Tabel 2 Hubungan kadar asam urat dengan tekanan darah pada lansia

\begin{tabular}{|c|c|c|c|c|c|c|c|}
\hline & \multicolumn{4}{|c|}{ Tekanan Darah } & \multirow{2}{*}{\multicolumn{2}{|c|}{ Total }} & \multirow[t]{3}{*}{$P$} \\
\hline & \multicolumn{2}{|c|}{ Normal } & \multicolumn{2}{|c|}{ Tinggi } & & & \\
\hline & $\mathrm{n}$ & $\%$ & $\mathrm{n}$ & $\%$ & $\mathrm{n}$ & $\%$ & \\
\hline Kadar Normal & 13 & 100 & 0 & 0 & 13 & 100 & 0,00 \\
\hline $\begin{array}{l}\text { Asam Tinggi } \\
\text { Urat }\end{array}$ & 3 & 14,3 & 18 & 85,7 & 21 & 100 & 01 \\
\hline
\end{tabular}

$\begin{array}{lllllll}\text { Total } & 16 & 47,1 & 18 & 52,9 & 34 & 100\end{array}$

Tabel 2 diketahui hasil uji chi-square nilai $\mathrm{P}=0,0001 \quad(\mathrm{P}<0,05)$. Maka, dapat disimpulkan ada hubungan yang bermakna antara kadar asam urat dengan tekanan darah pada lanjut usia (lansia) di Balai Pelayanan Dan Penyantunan Lanjut Usia (BPPLU) Pagar Dewa Kota Bengkulu Tahun 2018.

\section{PEMBAHASAN}

Hasil penelitian yang sudah dilakukan, didapatkan sebagian besar responden yang memiliki tekanan darah tinggi (52,9\%). Sebagian besar responden yang memiliki kadar asam urat tinggi $(61,8 \%)$. Hasil penelitian juga menunjukkan bahwa ada hubungan yang bermakna antara dua variabel yaitu kadar asam urat dan tekanan darah. Diketahui dari hasil analisis chi-square nilai $\mathrm{P}=0,0001 \quad(\mathrm{P}<0,05)$. Hasil penelitian ini sesuai dengan penelitian yang dilakukan oleh Umami tahun 2015 yang menjelaskan bahwa peningkatan kadar asam urat dapat menyebabkan tekanan darah tinggi, hal ini dihubungkan oleh pengaruh asam urat terhadap peningkatan stress oksidatif dan pengaktifan sistem renin-angiotensin, dimana hal tersebut dapat memicu disfungsi endothel, dan vasokonstriksi pembuluh perifer sehingga dapat menyebabkan tekanan darah meningkat (hipertensi) (Umami, 2015).

Asam urat merupakan faktor resiko bagi penyakit jantung karena asam urat merusak endotel (bagian dalam pembuluh darah) (Savitri, 2017). Peningkatan kadar asam urat dalam darah memiliki efek pada ginjal dan pembuluh darah, sehingga dapat menyebabkan penurunan NO (Nitrit oksida) dan peningkatan produksi renin/pelepasan renin sehingga mengakibatkan aktivasi langsung dari sistem renin-angiotensinaldosteron (RAA) (Pualillin. dkk. 2015) (Feig, 2012). Renin yang dilepas merangsang pembentukan angiotensin I yang kemudian diubah menjadi angiotensin II, vasokonstriktor kuat, yang pada akhirnya merangsang sekresi aldosteron oleh korteks 
adrenal. Hormon ini menyebabkan retensi natrium dan air oleh tubulus ginjal, menyebabkan peningkatan volume intravaskuler. Semua faktor tersebut cenderung mencetuskan hipertensi (Aspiani, 2014).

Hubungan antara hiperurisemia dengan hipertensi semakin diperkuat oleh studi eksperimental dengan hewan coba tikus yang dilakukan oleh Youssef pada tahun 2013. Pada studi tersebut, tikus diberi penghambat uricase, yaitu oxonic acid, kemudian diberi preparat asam urat. Ketika uricase dihambat, asam urat tidak dapat diubah menjadi allantoin yang bersifat lebih larut dan dapat diekskresi melalui urin. Setelah 1-4 minggu terjadi peningkatan tekanan pada darah tikus (Youssef, 2013).

Penelitian yang juga dilakukan oleh Feig tahun 2012 dengan menggunakan hewan percobaan tikus menunjukkan bahwa peningkatan kadar asam urat menyebabkan peningkatan tekanan darah secara bertahap pada hewan coba tikus. Pada penelitian yang dilakukan terdapat dua tahapan. Tahap pertama adalah asam urat mengakibatkan aktivasi langsung dari sistem reninangiotensin-aldosteron (RAA) dan mengurangi produksi nitrit oksida, yang menyebabkan vasokonstriksi. Pada tahap ini, penurunan kadar asam urat serum mengakibatkan relaksasi pembuluh darah dan memperbaiki tekanan darah (Feig, 2012). Tahap kedua, yang merupakan tahap lanjutan, adalah urate-mediated atherosclerosis. Asam urat terserap ke dalam sel otot polos pembuluh darah menyebabkan aktivasi produksi platelet derived growth factor (PDGF) dan monosit chemotattractant protein-1. Hal ini menyebabkan proliferasi abnormal sel otot polos vaskuler, penebalan dinding pembuluh darah, pergeseran kurva natriuresis dan pada akhirnya berujung pada perubahan morfologi vaskuler. Proses ini tidak dapat diperbaiki dengan diet rendah garam dan rendah asam urat yang kemudian dikenal sebagai sodium-sensitive hypertension (Feig, 2012).

Peningkatan kadar asam urat dalam darah memiliki efek pada ginjal dan pembuluh darah, sehingga dapat menyebabkan penurunan NO (Nitrit oksida) dan peningkatan ROS (Reactive Oxygen Species), inflamasi vaskuler dan proliferasi otot polos, peningkatan produksi renin dan lesi vaskuler pada ginjal. Proliferasi otot polos terjadi akibat aktivasi mitogen spesifik oleh asam urat. Walaupun otot polos tidak memiliki reseptor untuk asam urat, asam urat tetap dapat masuk ke dalam sel dengan bantuan organic anion transporter (OAT). Setelah masuk ke dalam sel otot polos, asam urat mengaktifkan protein kinase (Erk 1/2). Selanjutya Erk 1/2 akan menginduksi sintesis de novo dari COX-2 dan tromboksan lokal serta mengatur up regulation PDGF $A$ (platelet derived growth factor $A$ ). Hasil akhir proses tersebut adalah aktivasi mitogen spesifik yang menyebabkan proliferasi sel (Pualillin. dkk. 2015).

Asam urat juga menyebabkan akumulasi kristal urat di sekitar plak aterosklerosis yang telah terbentuk. Kristal urat tersebut dapat mengaktifkan komplemen melalui jalur klasik. Aktivasi komplemen mengakibatkan berbagai efek biologis seperti inflamasi, kemotaksis, opsonisasi, dan aktivitas sitolitik. Peningkatan asam urat juga akan menstimulasi sintesis MCP-1 (monocyte chemoattractant protein-1) pada otot polos. Caranya adalah dengan mengaktivasi p38 MAP kinase, faktor transkripsi nuklear, NF$\mathrm{KB}$, dan AP-1. MCP-1 sendiri merupakan kemokin yang berperan penting dalam penyakit vaskular dan aterosklerosis. Akibat dari mekanisme tersebut adalah peningkatan produksi sitokin proinflamasi seperti TNF-a, IL-1 $\beta$, dan IL-6. IL-6 yang juga dikenal sebagai hepatocyte stimulating factor merangsang hepatosit untuk memproduksi CRP. Senyawa kimia tersebut memicu proses peradangan sistemik. Menurut beberapa penelitian sebelumnya, peningkatan CRP juga akan menghambat enzim nitritoksidase sintase (eNOS) sehingga menurunkan produksi NO yang mengakibatkan disfungsi endotel (Pualillin. dkk. 2015) (Youssef, 2013) (Feig, 2012). 


\section{KESIMPULAN}

Sebagian besar responden yang memiliki tekanan darah tinggi dan sebagian besar responden yang memiliki kadar asam urat tinggi. Ada hubungan yang bermakna antara kadar asam urat dengan tekanan darah pada lanjut usia (lansia) di Balai Pelayanan Dan Penyantunan Lanjut Usia (BPPLU) Pagar Dewa Kota Bengkulu. Diketahui dari hasil analisis chi-square nilai $\mathrm{P}=0,0001$ $(\mathrm{P}<0,05)$. Dianjurkan untuk lansia agar mengatur pola makan dan mengontrol kadar asam urat ke fasilitas kesehatan, kemudian diharapkan penelitian selanjutnya dapat dilakukan dengan jumlah sampel yang lebih besar.

\section{SARAN}

Diharapkan kepada Peneliti selanjutnya untuk lebih mendalami Penelitian mengenai Hubungan kadar asam urat dengan tekanan darah pada lanjut usia (lansia).

\section{DAFTAR PUSTAKA}

Aspiani, R. (2014) Buku Ajar Asuhan Keperawatan Klien Gangguan Sistem Muskoloskeletal. Edited by W. Praptiani. Jakarta: EGC.

Badan Penelitian dan Pengembangan Kesehatan (2013) 'Riset Kesehatan Dasar (RISKESDAS) 2013', Laporan Nasional 2013, pp. 1- 384. doi: 1 Desember 2013.

Clement, J. et al. (2014) 'Nutrition \&amp; Food Sciences The Relationship between Uric Acid and Hypertension in Adults in Fako Division, SW Region Cameroon', J Nutr Food Sci, 4(4), pp. 1-4. doi: 10.4172/2155-9600.1000257.

Feig, D. I. (2012) 'Hyperuricemia and Hypertension', Advances in Chronic Kidney Disease. Elsevier Ltd, 19(6), pp. 377-385. doi: 10.1053/j.ackd.2012.05.009.

Novitasari, A. and Tatius, B. (2014) 'Hiperuresemia Meningkatkan Risiko
Hipertensi Hiperuresemia Increases Risk of Hypertension', universitas muhammadiyah semarang, 2025, pp. 17.

Pualillin, R., Rampengan, S. H. and Wantania, F. (2015) 'Hubungan Kadar Asam Urat dengan Kejadian Gagal Jantung Akut pada Pasien Hipertensi', Jurnal e-Clinic (eCl), 3(April), pp. 368-375.

Qiu, L. et al. (2013) 'Prevalence of hyperuricemia and its related risk factors in healthy adults from Northern and Northeastern Chinese provinces', BMC Public Health, (5).

Savitri, D. (2017) Diam-Diam Mematikan, Cegah Asam Urat Dan Hipertensi, Healthy. Yogyakarta: Healthy. doi: 10.1590/S1516 18462008000300012.

Sofia, R. and Gusti, Y. (2017) 'Hubungan Depresi dengan Status Gizi Lansia di Panti Sosial Tresna Werdha Belai Kasih Bireuen', Ilmiah Sains, Teknologi, Ekonomi, Sosial dan Budaya, 1(1), pp. 54-60.

Syahfitri, A. and Joseph, V. (2016) 'Gambaran kadar asam urat pada pasien sindrom koroner akut di RSUP Prof. Dr. R. D. Kandou Manado periode JanuariDesember 2015', Jurnal e-Clinic (eCl), 4.

Umami, H. (2015) 'Hubungan antara peningkatan kadar asam urat darah dengan kejadian hipertensi di RSUD Sukoharjo', universitas muhammadiyah surakarta,pp. 112.

Youssef, M. (2013) 'Is Hyperuricemia A risk Factor to Cardiovasculer Disease?', INTECH, pp. 123-131. doi: $10.5772 / 711$. 